\title{
Sound Waves: "Blue Ecology" in the Poetry of Robin Robertson and Kathleen Jamie
}

Ondes sonores: des « écologies bleues » en poésie écossaise contemporaine

\section{Alexandra Campbell}

\section{OpenEdition}

\section{Journals}

Electronic version

URL: http://journals.openedition.org/etudesecossaises/1199

ISSN: $1969-6337$

\section{Publisher}

UGA Éditions/Université Grenoble Alpes

\section{Printed version}

ISBN: 978-2-37747-001-3

ISSN: $1240-1439$

\section{Electronic reference}

Alexandra Campbell, «Sound Waves: "Blue Ecology" in the Poetry of Robin Robertson and Kathleen Jamie ", Études écossaises [Online], 19 | 2017, Online since 01 April 2017, connection on 08 September 2020. URL : http://journals.openedition.org/etudesecossaises/1199

This text was automatically generated on 8 September 2020

(c) Études écossaises 


\title{
Sound Waves: "Blue Ecology" in the Poetry of Robin Robertson and Kathleen Jamie
}

Ondes sonores : des « écologies bleues » en poésie écossaise contemporaine

\author{
Alexandra Campbell
}

1 Described as a "dynamic model of geography" that is explicitly tied to island cultures, the concept of "tidal dialectics" or "tidalectics" works through the elucidation of the relationship between maritime history and cultural production, providing a "framework for exploring the complex and shifting entanglement between sea and land, diaspora and indigeneity, and routes and roots" (DeLoughrey, 2007, p. 2). First posited by the Bajan poet Kamau Brathwaite, the "tidalectic" foregrounds an openended "ripple and [...] two tide movement" that actively considers the spatial and historical construct of island cultures (Naylor, 1999, p. 143). Presented as an alternative historiography to linear (colonial) models of temporal progress, the tidalectic takes its inspiration from the constantly changing coastal landscapes and seascapes of the Caribbean archipelago that is characterised by a "tangled urgent meaning to \& fro" (Braithwaite quoted in Naylor, 1999, p.162). Tracing ripples of connection and communication Brathwaite's tidalectic thought gives voice to a myriad of submerged cultures, histories, and ecologies. This article will explore how the contemporary work of Scottish poets Kathleen Jamie and Robin Robertson similarly engage the space of the Atlantic archipelago as a means of exploring this "shifting entanglement" between poet and place. Across their collections the coasts, oceans, and seas of the Atlantic archipelago are positioned not only as powerful metaphorical sources, nor merely as sites of transnational crossings and connections, but as material sites that bear the traces of environmental decline. Focusing on two collections, Jamie's The Tree House (2004) and Robertson's The Wrecking Light (2010), this article presents a series of "blue ecological" readings of their work, and suggests that their archipelagic practice signals a wider trend of oceanic thought within modern Scottish poetry. 
2 Archipelagic frameworks have increasingly been applied to the space of the "British Isles" in an attempt to "uncover the long braided histories played out across the British-Irish archipelago" (Kerrigan, 2008, p. 2). Such models are akin to Brathwaite's tidalectic as they stress the significance of the intermingled histories, languages, and locations, that wind their way across the Atlantic archipelago. Importantly, archipelagic frameworks encourage a re-orientation of Anglocentric paradigms that cast Scotland as a "marginal" and "fringe" space, and encourage a view of Scottish culture as "pelagic maritime and oceanic into which an extraordinary diversity of cultural and other movements has penetrated deeply" (Pocock, 2005, p. 78). This critical movement towards the "pelagic maritime and oceanic" is reflected in the recent rise of what scholars have begun to term "blue cultural studies" or the "blue humanities" (Brayton, 2012, p. 198). The school of "blue" ecocriticism has risen in response to the landed discourse of "green studies" and suggests that by embracing the interlinking quality of the "Global Ocean" we might begin to recognise that the oikosthe place of dwelling-is not always dry (ibid., p. 28). In relation to the work of Jamie and Robertson, I suggest that blue ecologies serve a dual function: firstly, they prompt us to consider the relationship between saltwater and place, and secondly, they enable a reorientation of the critical axis away from Anglocentric paradigms of space. Their collections present the archipelago as "a world of connection, networks, flow, openness, leakiness and change" that encourages a terrestrial ecocritical discourses to embrace a more terraqueous mode of reading place in contemporary Scottish poetry (Peters \& Steinberg, 2014, p. 125). ${ }^{1}$ Through their ecopoetic practice both Jamie and Robertson interrogate "the complex relationship between poetry and place, and frequently address the significance of depths, tides, coastal environments, whales, fish, and winds" in establishing new entanglements between human and nonhuman worlds (Brayton, 2012, p. 198).

Defined as a form of poetry that responds to environmental crisis, ecopoetry "enacts through language the manifold relationship between the human and the other-thanhuman world" (Fisher-Wirth \& Street, 2013, p. xxx). The recent emergence of blue ecology attempts to establish the equal importance of waterscapes within this relationship between nature and culture. Importantly, this poetic turn towards the blue does not attempt to perform an absolute break with the landed "green" discourse of ecopoetic traditions, but instead highlights the peculiar absence of saltwater narratives in contemporary ecocritical scholarship. In the recent work of Steve Mentz and Daniel Brayton the turn towards saltwater enables the emergence of fresh ecocritical perspectives which contest the "stable" and grounded discourses of "green" ecology (Mentz, 2015, p. xxIx). Regarding the role of the ocean within the works of Shakespeare Brayton suggests, "Ecocritical scholarship to date has been almost entirely terrestrial outlook" (Brayton, 2011, p.173). While Brayton's assessment may be slightly exaggerated, it is undeniable that large strands of ecocritical discourse have their theoretical basis in modes of reading the earth in which place "is conceived as stable, familiar and intimately knowable" (Alexander, 2015, p. 73). This construction of place is arguably characteristic of "first wave ecocriticism" (Buell, 2005, p. 17), ${ }^{2}$ in which the act of dwelling "bespeaks permanence and continuity" that promotes a "kind of rooted being" and explicitly emphasises "continuity, authenticity, and oneness" between the human and non-human environment (Alexander, 2015, p. 72-3). As Ursula Heise notes, this first-wave critical stance is not in keeping with movements in scientific ecology which have since moved away from holistic notions of "interconnectedness, stability 
and harmony" and have instead turned towards a "more complex image of ecosystems as dynamic, perpetually changing, and often far from stable or balanced" (2006, p. 510). Similarly, in his engagements with what he terms "Shipwreck Modernity", Steve Mentz explores "the human-ocean encounter at its most violent and intimate" (2015, p. XXVIII) as a means of redirecting "stable" green ecocritical scholarship towards the dynamism of the ocean. In so doing, Mentz characterises the turbulence and magnitude of oceanic space as a "powerful antidote" for "representations of landed stability" (Mentz, 2009a, p. 1007). For both Brayton and Mentz, it is by looking toward the blue ecologies of "invisible submarine world of shoals, shelves, banks, sands, and tides" (Brayton, 2012, p. 198) that we may begin to consider more dynamic and protean models of contemporary ecocriticism that engage both global concepts of place and "neobioregionalist attachments to specific locales" (Slovic, 2010, p. 7). The work under consideration in this article in corresponds to a new palimpsest of ecocritical thought which extends the scope of "terrestrial", "green" and "landed" discourses into the blue.

Looking to the discipline of Human Geography a more specific outlining of blue ecology can be identified. In a similar vein to Mentz and Brayton, Kimberley Peters and Jon Anderson note how the discipline of Geography has traditionally stemmed from terrestrial and earth-based discourses within which the oceans and seas are "not accorded the status of 'place' worthy of scholarly study" $(2014$, p. 3). The dismissal of the seas and oceans within geographical study has led to a characterisation of the ocean as "a quintessential wilderness, a void without community other than that temporarily established on boats crewed by those with the shared experience of being tossed about on its surface" (Mack, 2011, p. 17). This portrayal problematises conceptions of saltwater bodies as "empty", void of history, "a space not a place" (ibid., p. 16). This problematisation of saltwater place is succinctly noted by Philip Steinberg:

The ocean is constituted by vectors of movement-tides, currents, and waves-but these vectors do not simply occur in the ocean; they are the ocean. As such it is impossible to 'locate' a point at sea as an actual material place. Baudrillard's [...] observation about the map preceding the territory is as true at sea as it is on land. But in the ocean there is a further iteration because the territory subsequently washes away the map. Thus we can never truly 'locate' ourselves within the ocean. Or, if we must locate ourselves, we require a different kind of map. (Steinberg, 2014, p. Xv)

Here, the oceans and seas are cast in opposition to a form of "sedentary metaphysics" in which the process of place-making "involves carving out "Permanences"' which correspond to territorial categorisations of the world as "fixed, static and durable" (Peters \& Anderson, 2014, p. 11). This inability to locate "place" complicates ecocritical perspectives that consider rooted or grounded "place-attachment" as a key component of environmental discourse. Rather than espousing "sedentary and surficial notions of "place" the oceans and seas allow us to consider notions of "a dynamic world of relational becoming", a "wet ontology" in which place is revealed through "partial encounters" with ocean creatures and environments (Peters \& Steinberg, 2014, pp. 125, 129). Blue ecology is therefore identifiable as a mode that not only engages the oceans and seas of the world, but is specifically concerned with the ways in which saltwater affects and shapes our relationships with place. For Peters and Steinberg, this spatial reorientation is directed through the concept of a "wet ontology" which takes "space, time, and motion" as its key nodes of engagement (2015, p. 249). These coordinates of space, time and motion provide the bearings for the following analysis of Jamie and Robertson, paying particular attention to their respective treatment of time, "partial 
encounters" with aquatic creatures, and the mobility of marine environments. It is by actively looking to those ecopoetic narratives that are produced by, on, or near the sea that we may begin to understand the ecological and cultural significance of the sea in contemporary Scottish writing.

\section{"Watching the ocean move": Robin Robertson's sea verse}

5 The terrestrial discourses which take the "earth" as their key domain of concern easily lend themselves to linear trajectories of time which stabilise "history into material strata and immaterial epochs that can be neatly bordered, bounded, and contained" (Peters \& Steinberg, 2015, p. 255). In contrast, as I have suggested, blue ecology locates history within a rippling and dynamic "tidalectic" movement that disrupts any notion of constancy or containment. Indeed, the "churning" and undulating activity tides, waves, and currents "suspends and distorts terrestrial markings of temporality" (DeLoughrey, 2007, p. 55). Importantly this "suspension" of temporality does not mean that seas and oceans are void of history, rather it reflects the physical action of being suspended "as particles, in a medium" (OED, 2016, web). This section argues that the sea in the poetry of Robin Robertson, provides a site of poetic suspension in which the "bounded and contained" control over time and space breaks down.

Robertson's The Wrecking Light (2010) engages a multitude of modern and mythic seascapes. Across the collection Robertson roves from Scottish seascapes in the Outer Hebrides to the North East Coast, and beyond to Northern Ireland, India, Sweden, Northern Italy and Ancient Greece. The collection is driven by an impulse to navigate towards a sense of "home". Across the text we encounter a series of Odyssean style voyaging poems that are shaped by motions of departure and arrival. Described by Robertson as a "very watery book", The Wrecking Light embraces the "mythic wordhoard of Celtic stories" and is saturated with a sense of his childhood landscapes from the North East of Scotland and more recent travels abroad (Robertson, 2010b, n. pag.). Split into three parts, "I: Silvered Water", "II: Unbroken Water" and "III: Unspoken Water" the collection places water at the centre of its engagement with place. Across the collection, the sea provides the location for a continuous interplay of temporalities where myth, memory and folklore are held in suspension, mixing and intermingling across various time frames. For example, Robertson takes great care to note the folkloric roots of "silvered" and "unbroken" water, describing the rituals of placing silver coins in water for the enactment of a "traditional Scottish blessing, or preparation for a wish" or healing "charm[s] against the Evil Eye" (2010, pp. 93-4). His choice of titles reflects an understanding of water as both a reservoir of human tradition, as well as an uncanny and biodeverse habitat.

7 In one of the most impressive poems of the collection, "Leaving St Kilda", the speaker of the poem traces the land and seascapes of the Outer Hebridean archipelago as they watch the islands stream past on board a boat departing in the wake of the 1930 evacuation. Place names, in both Gaelic and English, are the only reference points for the poem. Throughout the sequence, names are rhythmically chanted in an order which provides an "anti-clockwise circumnavigation of the main island Hirta, then Soay, followed by a clockwise turn around Boreray" (Robertson, 2010, p. 94). Following 
these iterations, we move from the "edge of Mullach Mor" and "Village Bay" through a series of sea stacks and clefts

[...] to The Hoof, and the Cleft of the Hoof, to The Gap

where the fulmars nest in their sorrel and chickweed;

and on to Stac a'Langa, the Long Stack

also called the Stack of the Guillemot, and Sgeir Dhomnuill.

(Ibid., p. 25)

The litany of naming enacts a memorialisation of the human histories which slowly give way to the nonhuman attentions of wind, wave and kittiwake. Across the sequence, the speaker is not only attentive to the places of human history (at last count over 100 place names are cited), but is acutely drawn to the biodiversity of the islands, noting "four mammal, three plant and fifteen bird species" which continue to thrive in their thousands (MacKenzie, 2013, p. 204). These sites "thrumming and ticking / with the machinery of sixty thousand squalling birds" indicate an intimate linkage between the human and nonhuman (Robertson, 2010, p. 28). The animalistic names of "The Hoof", "The Beak of the Wailer", "Cleft of the Grey Cow" reveal the community of St Kilda to be one that is tightly knit to the ecosystem of the islands (ibid., pp. 25-8).

Through this interplay the poem consistently draws connections between human and natural histories, where depending upon perspective, the "Gannetry of St Kilda: Stac Lee" is "From one side a bishops piece, from another, a shark" (Robertson, 2010, p. 28). The poetic encircling ensures that both perspectives: chess piece or shark fin, are equally portrayed. As we circumnavigate the archipelago we see how these sites, seemingly reclaimed by "puffins, petrels, shearwaters" are equally storied by human narratives (ibid., p. 26). In so doing, Robertson establishes the archipelago as a site of ecological relation, where humans are but one (departing) part of a wider ecosystem. As the sequence continues, the interplay between human and nonhuman history continues. Moving past places such as "The Well of many Virtues", the "Cairn of the Green Sword", and the "Chasm of the Warrior", the speaker acknowledges a long history of human habitation and tradition (ibid., pp. 25-9). As the boat navigates the waters of the St Kilda archipelago the poem acknowledges the on-going and historical interconnection between human and nonhuman beings. Sailing past

[...] the northern stack: Stac an Armin, Stack of the Warrior,

highest sea-stack in these islands of Britain, where the last

great auk was killed as a witch

a hundred and seventy years ago.

(Ibid., p. 28)

Here, Robertson constructs a poetic link between human and nonhuman history where the extinction of the "great auk" echoes the current evacuation of the islands. By Juxtaposing 19th century extinction, alongside the modern evacuation of the island, Robertson reveals how time shifts "Out on the ocean" (ibid., p. 26). The iambic rhythms, changing line length, and consonance of the text echoes the sound and movement of waves and tides that have through "centuries of close attention" forged the very "arches, pillars, clefts and caves" that the boat attempts to navigate (ibid.). Through these anachronic attentions, the archipelago is shown to be deeply bonded to a sense of "ecological time" which "situates human activities in a cyclical relationship with a natural environment that also bears the imprint of ancestral activities" (Heim, 2010, p. 149). The ritualistic anti-clockwise encircling of the islands prohibits and disrupts the progression of linear time, suspending acts of enclosure and containment. The constant and careful navigation of sea stacks, arches and inlets keeps the poem attuned 
to the active movement of the boat which appears to be moving through both time and space. As the poem navigates the rich waters of the archipelago the fleeting engagement with the islandscape and abundant marine life draws a constant flow between distant memories and continuous acts of arrival and departure.

As the poem closes, the actual act of leaving St Kilda is shown to be a balance between human and natural forces. In the closing stanzas the island shifts between a great "mountain range" and a human figure described as having "shoulders" adorned by a "shawl" of sea mist (Robertson, 2010, pp. 28-9). Unable to draw their eyes away from the "great sea-citadel" that was once their home the departing figures "hold the gaze of the rocks" as if spellbound, refusing to look away (ibid., p. 29). It is only when the natural forces of the ocean "close over" the archipelago, the islands "returning to the waves", that "At last we turn away" (ibid.). Yet, as the boat begins to move east, the passengars are escorted by "bow-riding dolphins, our grey familiars, and thirty gannets" (ibid.). Protected by a "gannet guard" as they begin their "far passage, / for the leaving of St Kilda", the poem establishes the continuation of human connection to the sea where the itinerant action of the gannets "in a line / drawing straight from Borerary" corresponds to the departing movement of the humans aboard the boat (ibid.). Interestingly, the hopeful flight of the seabirds contests the finality of the closing stanza where rather than signifying an absolute departure, instead hints at the possibility of a migratory return (ibid.).

Across The Wrecking Light the sea becomes a site of temporal dislocation and uncanny habitation, its unmappable waves and constant flow impart a sense of disruption to any form of stable dwelling. In "Easter, Liguria" a speaker "watching the ocean move" is troubled by the people surrounding him "going home, and I realise / I have no idea what that means" (Robertson, 2010, p. 81). Tuning in to the "shrieking of the gulls" overhad, the speaker contemplates "How long have I been leaving? / I don't know" (ibid.). Here the ocean vista disrupts not only a sense of dwelling and home, but also prohibits a sense of temporal location. Across the collection, saltwater is repeatedly revealed to be a disruptive element that prohibits the comprehension of stable time and place. Importantly, saltwater is also shown to retain roots of myth and tradition. In the penultimate poem "At Roane Head", which won the Forward Prize for best single poem in 2009, we can see how the ocean becomes a mechanism of subversion that destabilises a sense of human dominion and stable notions of home. Recounting the violent folkloric story of a woman and her four sons, "At Roane Head" takes the myth of the selkie as its central narrative. ${ }^{3}$ From the outset of the poem the speaker crafts a peculiar and unsettling atmosphere of familiarity and strangeness. The opening lines: "You'd know her house by the drawn blinds - / by the cormorants pitched on the boundary wall, / the black cross of their wings hung out to dry" (ibid., p. 87) intimates a personal knowledge of place, in which the house and woman are "known". Yet the images of shuttered windows, sinister cormorants, and "Aonghas the collie, lying at the door / where he died: a rack of bones like a sprung trap" instantly disturb and unsettle, with the enjambment of the line subverting any form of comfortable homestead or ability to truly "know" (ibid.). As the poem continues, the image of the bound and bereaved house that lies hidden from the sea is placed in opposition to its occupants who display a peculiar affinity for the ocean. Describing the woman's four sons the speaker notes that all were born "wrong", "All born blind, they say, / slack-jawed and simple, web-footed" (ibid.). Uncomfortable on land, they walk "rickety as sticks" with a 
"hirpling" gait, yet "were fine swimmers" described as "more fish than human" with "herring-eyes" (ibid., pp. 87-8). Due to their comfort and affinity with the sea, the children are described as variously as "wrong", "beglamoured", and the products of "witchery" (ibid.). Here Robertson crafts the central tension of the poem in which neither sea nor land offers safe refuge or security.

This discomfort culminates in a violent scene in which the husband returns to the home "thick with drink" and (rightly) convinced that the children "couldn't be his" (Robertson, 2010, p. 88). Forcing the children to stand "in a row by their beds" the husband moves "along the line / relaxing them / one after another / with a small knife" (ibid.). Notably, the killings are not a portrayed as a spectacle, but are presented as a slow, intimate, and familiar act, akin to an angler gutting fish. Despite their disturbing and uncanny presences, it is not the selkies that are depicted as the source of violence, but the human figures. The poem closes on the wife presenting to the speaker a series of tokens and gifts: "She gave me a skylark's egg in a bed of frost: / gave me twists of my four sons' hair; gave me / her husband's head in a wooden box." (Ibid., p. 89) Once again, the enjambment of Robertson's lines destabilises the expectations of the reader, disrupting the flow of narrative to produce unforeseen consequences. By depicting the death of the husband at the hands of the wife, Robertson subverts the familiar Scottish folktale in which the romantic tragedy typically ends with the death of both selkie child and parent; instead, we are left with the speaker who at the culmination of the poem dons "the sealskin", revealing his true nature. The donning of the skin at the end of the poem effectively restarts the narrative; having escaped death the speaker is free to continue his ways, to return to the sea, to find a new home and begin a new line.

Across his work Robertson espouses a form of wet ontology which disrupts the "linear trajectory of time that stabilises history" (Peters \& Steinberg, 2015, p. 255) and instead proffer notions of time that are nonlinear and non-teleological. This lack of liner time and temporal control establishes a new ecology in which the human figure is set afloat within a sea of both human and nonhuman histories; cast adrift these figures must fathom new modes of relation in which the human is no longer the primary subject, and concepts of place are no longer stable.

\section{Tilting, listing, listening: Kathleen Jamie's sound waves}

13 The watery navigation of place and dwelling is also evident within Kathleen Jamie's 2004 Forward Poetry Prize winning collection The Tree House. While Robertson's verse disrupts the continuity of history and progression of linear time through the chanting incantations of myth and folklore, Jamie's lyrical works delve into the function of poetry itself as a means of connecting or establishing relations with place. While both Jamie and Robertson are avidly tuned to the aural dimensions of the sea, Jamie's works express a more overt fascination with the acoustic dimensions of poetry, espousing a poetics of attention that is drawn to the ecological ethics of listening. The aural dimensions of her collections engage with and extend the function of ecopoetics as proposed by Jonathan Bate, who suggests that within poetry "metre itself-a quiet and persistent music, a recurring cycle, a heartbeat-is an answer to nature's own rhythms, an echoing of the song of the earth itself" $(2001$, p. 76). These sound waves reverberate 
throughout The Tree House (2004) and presents poetry as a relational force which embraces the entire spectrum of human and nonhuman life across the Atlantic archipelago.

Yet from the outset of The Tree House, "the earth" is shown to be a problematic term for Jamie. The opening poem "The Wishing Tree" provides a triangulation point for the ethos of the collection, promising a string of work that considers the "tilt from one parish / into another" (Jamie, 2004, p. 3). Proclaiming that within this hinged space, "I stand neither in the wilderness / nor fairyland (ibid.) Jamie opens the collection with a decided statement against familiar forms of Romantic nature writing, and the secure "land ethic" of contemporary ecopoetry. Further to this, we can see how in "The Wishing Tree", the speaker-presumably the tree-is tuned to the liminal spaces of the landscape, situated somewhere in-between, extending "towards the Atlantic" (ibid., pp. 3-4). The "tilt" Jamie describes, unsettles stable ground and places the reader within sites of transformation and change. This hesitation surrounding the stability of "earth" complicates Bate's conception of ecopoetics as a form that proposes "that harmonious dwelling with the earth is a matter of staying put and listening in" (ibid., p. 29). Jamie's poems most certainly do not stay put. For example, in "Landfall" she plays with the definition of the word that signifies both the arrival at land after a sea voyage, but also the collapse of land. The single stanza poem undergoes a series of transformations as the speaker's attentiveness to the landscape shifts in an act of noticing:

When we walk at the coast

and notice, above the sea,

a single ragged swallow

veering towards the earth-

$[\ldots]$

can we allow ourselves to fail.

(Jamie, 2004, p. 15)

The inclusion of the comma after "notice" creates a pause within the poem, allowing room for both reader and speaker to become attentive to the scene before them. The initial vista of the coastal path opens up to include the sea, the sky, and a cleft form of "earth-" (ibid.). Looking upward toward the "ragged swallow", the poem is instilled with a sense of vertigo as the bird suddenly plummets towards the earth. This sudden "veering" is akin to the opening "tilt" of the collection-a destabilising action that unbalances our position within the world, enabling us to adopt new perspectives from points of disruption.

Similarly, within "The Bower" we see Jamie play with the dual signification of words, and the destabilising motion of poetry. Signifying both a woodland dwelling and a form of anchor, "The Bower" explores fluid notions of dwelling. The familiar image of a forest bower is immediately placed into question with the opening lines "Neither born nor gifted / crafted nor bequeathed" indicating that once again this is a poem concerned with thresholds and instability, and acutely wary of Romantic forms of nature (Jamie, 2004, p. 17). As the poem progresses, the "entailed estate" of the bower is shown to be formed from "nothing / but an attitude of mind / mere breath rising in staves" at once an "anchorage/ or musical box, veiled / and listing deep" (ibid., p. 17). Music becomes an integral component of Jamie's poetics, enabling an engagement with "patterns of repetition and fracture" (Falconer, 2015, p. 157) involving both biotic and abiotic forms within the environment. Through a continual flow of loose rhyme, 
assonance and consonance the poem expresses its "need / to annunciate" the song of the earth (Jamie, 2004, p. 17). However, in revealing that this "dwelling's / little but warp or tease / in the pliant light" (ibid.), Jamie once again provides us with an unbalancing "tilt" of earth. This "plaint" quality of language and landscape combines throughout "The Bower" through a continued interplay of musical and maritime terms. The mixing of musical and maritime terms (e.g. warp, stave, listing, anchorage, waves) initially seems out of place within the apparent forest setting, but is in fact an essential component for the function of "return" which steers the poem. The marine language used throughout enables the poem to engage in a dynamic of arrival and departure where dwelling becomes a mobile act of "anchorage", partial encounter, and a continued resonance.

Importantly, both "The Bower" and "Landfall" end on an open line enacting a resistance towards bounded enclosure and instead embrace reverberation. Jamie's closing question in "Landfall", "can we allow ourselves to fail" resounds outwards, encouraging further engagement and prompting a form of communication between poet, person and place. Similarly, within "The Bower" the open-ended final quatrain enables a sense of continued engagement:

But when song, cast

from such frail enclaves

meets the forest's edge,

it returns in waves.

(Jamie, 2004, p. 17)

The multiple "waves" of return encourages us to think of poetry as a practice of exchange, where the vocal and aural engagement with the landscape incurs a relational musicality between human and nonhuman. Returning in waves, both "Landfall" and "The Bower" implement ocean and sea imagery as a means to disrupt static notions of "earth". By engaging the ocean Jamie's poems begin to "veer", "list" and "tilt" away from stable concepts of dwelling and prompt us to retune our attention towards wet ontologies which are concerned with "flows, connections, liquidities and becomings [...] of a world ever on the move" (Steinberg \& Peters, 2015, p. 248). Much as a boat "tilts" or "lists" towards one side, unbalanced by the churning motion of waves and tides, so Jamie's poetry unsettles stable points of anchorage and place. Her continued attentions to transient spaces and shifting landscapes extends Bate's readings of ecopoetry as a static practice of listening, and instead proffers a vision of poetry as a reciprocal act of attentive communication, foregrounding "the fluid and unfinished act of poetic making as enactment of and attention to a fluid and transforming world" (Davidson, 2015, p. 93).

While saltwater is used in a figurative sense within "Landfall" and "The Bower", Jamie also turns to the "dynamic three dimensional materiality" (Peters \& Anderson, 2014, p. 8) of the sea in a loose sequence of poems focused on "partial encounters" with aquatic creatures. In "White-sided Dolphins" the speaker mimicking the "urgent cut and dive" of the dolphin flings themselves "flat on the fore-deck" at the appearance of the creatures, their bodies both skimming the surface of the sea and enabling a moment of connection where "just for a short time / we travelled as one" (Jamie, 2004, p. 22). Despite the human figure clutching a camera, it is the dolphins who "careen and appraise us / with a speculative eye" (ibid.), the sea inverting anthropocentric power relations which would normally position the human at the centre of the act of observation. Satisfied with their appraisal the dolphins "true to their own / inner 
oceanic maps" are the ones to end the encounter, veering off "north by northwest" (ibid.). Once again we encounter a sense of "tilt" in the poem, where the careening and veering action of the dolphins blurs the distinction between animal, human and maritime vessel.

In "Basking Shark", the human speaker begins the poem by laying down upon a "cliffedge", providing a new line of sight which enables the figure to penetrate the depths of a "green- /tinted sea, so clear / it revealed, level below level, / not void, but a living creature" (Jamie, 2004, p. 23). From the precarious position at the edge of the earth, the speaker is able to perceive the seascape below as not merely a void expanse of water, but a thriving biodiverse harbour in which is currently "berthed" a magnetic creature (ibid.). The poem crafts a meeting point in which both shark and human, lying prostrate at the edges of their respective elements, encounter the "limits of its realm" (ibid., pp. 23-4). While the optics of the encounter are important, the speaker declaring repeatedly "what could one do but watch?", the aural elements of the poem attempts to find balance within the "peculiar backwash" of the seascape (ibid., p. 23). The soundscape of the poem echoes acts of buoyancy, or suspension, where through a "corrective rippling" the lines navigate the varying levels of the sea (ibid.). The heavy plosives of "dull dark", "peaceable and dumb" mimic the weight of the "ore-heavy body" of the shark "steady / as an anvil" which rests "buoyed like a heart" at the surface (ibid., pp. 23-4). The breathy cadence of the closing alliterative lines "waited, and was watched; / till it all became / unbearable, whereupon the wind / in its mercy breathed again" counteracts the heaviness of the preceding stanzas, the internal rhymes elevating the poem from the depths and up towards the sea-air (ibid., p. 24).

19 The final poem in this attentive sequence, "The Whale-watcher", begins again at the edge of earth, occurring at the moment where "the road gives out - " into a mix of "harsh grass, sea-maws, / lichen-crusted bedrock -" (Jamie, 2004, p. 25). The solid dashes mark the transition of the speaker from a purely anthropocentric domain into a relational and entangled dwelling place. The acoustics of the poem similarly change within this breakage, the long drawn out vowel sounds of the "road" cracking into the sibilance of "harsh grass" and consonance of "lichen-crusted bedrock" conveying the new soundscape of the ocean edge. The poem continues to forge a sonic connection between person and place, the "battered caravan" the speaker takes residence in echoing the "brittle waves" beyond (ibid., p. 25). Much like "Basking Shark" and "White-sided Dolphins" the position of the speaker as "watcher" soon shifts as the aural dimensions of the poem take precedence. Indeed, we are told that the whalewatcher stares at the sea "until my eyes evaporate", the water becoming nothing but a bright "glare" necessitating a new mode of poetic attention (ibid.). No longer reliant on visual connection the poem engages an ethics of listening, in which the open vowel sounds of "breach, breathe and dive" effectively "repair" the harsh consonance of the preceding unrhymed quatrains with their brittle, battered and broken sounds (ibid.). The full rhyme of "glare" and "repair" closes the final quatrain with a sense of restoration, in which the "rent" ocean is stitched together by the movement of the whales, presenting a hopeful scene of environmental recovery.

Across her work, ${ }^{4}$ Jamie engages Scotland's seas and coasts as a membrane which blurs the threshold between human and nonhuman worlds, her collections continually attentive to "porous edges and interpenetrations of being" (Falconer, 2015, p. 158). Her interplay of optic and acoustic modes of attention allow her poems to move beyond a 
distanced observation of the natural world and instead present the speaker as but one component of a reverberating and resonant environment. Looking to the various patterns and levels of the sea her poems "churn" seemingly stable space, allowing us to progress "on some sudden new trajectory" which is participatory, reciprocal and always questions how we might find "a way to live / on this damp ambiguous earth?" (Jamie, 2004, pp. 7, 21). Never quite "staying put" her work moves beyond the incantations of a steady and stable "song of the earth", and embraces the fluidity and mobile song of the sea.

\section{Conclusion: blue ecologies and archipelagic poetics}

Due to scope, this article has limited discussion to only two poets and two collections. However, when looking to the current field of contemporary Scottish poetry the significance of saltwater narratives and blue ecologies become readily apparent. An extended study might include the itinerant "geopoetics" of Kenneth White, the eachscapes of John Burnside's numerous collections, the tidal works of Valerie Gillies, the Shetland seascapes of Jen Hadfield, or the recent "poetic primer" Ebban an Flowan (2015) by Alec Finaly and Laura Watts' regarding marine renewable energies in the Orkney islands. The discussion presented here is thus not exhaustive, but is instead offered as a means of opening the critical landscape to include and promote new "blue" readings of contemporary Scottish writing. The rise of blue ecologies within contemporary Scottish poetry reorientates the critical and creative axis away from continental and landed perspectives of place. Presenting saltwater space as an infinitely relational zone these poets continue a mode of writing that has begun a "diverse project of literary re-mapping in the British and Irish archipelago" (Smith, 2012, p. 2). Signifying any "sea, or sheet of water, in which there are numerous islands" (OED, 2016, n. pag.), the archipelago is a site which allows for a productive reimagining of the space of Scotland, both physically and poetically. The numerous islands and coastlines of Scotland feature prominently within the works of Jamie and Robertson, their poems continually navigating connective routes across saltwater space. To close this article, I would like to suggest that the blue ecologies of Jamie and Robertson not only engage with a new "wet ontology" that repositions human engagement with the natural world, but also engage with oceans and seas as a means of enacting a "spatial turn" within contemporary Scottish literature.

In tandem with the rise of blue ecology, archipelagic models have gained increasing traction within contemporary Anglophone literary studies, and are often found in relation to texts concerning the "geo-political unit or zone, stretching from the Channel Islands to the Shetlands, from the Wash of Galway bay, with ties to North America and down to the Caribbean" (Kerrigan, 2008, p. vII). By engaging the fluidity and mobility of sea space the term archipelago "designates a geopolitical unit or zone [...] neutrally (avoiding the assumptions loaded into 'the British Isles'); and it implies a devolved, interconnected account of what went on around the islands" (ibid.). Within a contemporary Atlantic context, archipelagic criticism allows us to reassess the Anglocentric ideologies which have ignored the "long, braided histories played out across the British-Irish archipelago between three kingdoms, four countries, divided regions, variable ethnicities and religiously determined allegiances" (ibid., p. 2). At its core archipelagic literature opens previously closed island imaginings which have for 
so long focused on insular and continental paradigms which focus on borders and boundaries between land and sea, island and mainland. Instead, the archipelago emphasises "connections between "island and island" and prompts us to seriously consider how this new spatial assemblage might unsettle "static tropes of singularity, isolation, dependency and peripherality that presently dominate how islands are conceptualized in [...] literature" (Pugh, 2013, p. 11). The works of Jamie and Robertson engage the broad and "pliant" seascapes of Scotland as a means of crafting "a different kind of map", one that attends to the continuously fluctuating contours of the coast, and the multiplicitious histories and languages of the islands. Their tidalectic lyrics embrace the ever-changing sites of saltwater space in a means to recalibrate, and "tilt" our attentions to the more-than-human world. Further to this, their inclusion of Scottish myths, folklore and fable provides a different historical source material for the consideration of place and time, one that is unequivocally attentive to Celtic coast. In so doing, their works become exhibitive of a new archipelagic poetics, a form of practice that embraces the shifting entanglements of land and sea, poetry and place.

\section{BIBLIOGRAPHY}

“Archipelago, n.”, 2016, OED Online, Oxford University Press (consulted 6 September 2016).

ALEXANDER Neal, 2015, "Shorelines: Littoral Landscapes in the Poetry of Michael Longley and Robert Minhinnick", in U. Kluwick and V. Richter (eds), The Beach In Anglophone Literature: Reading Littoral Space, London, Routledge, pp. 71-87.

BATE Jonathan, 2001, Song of the Earth, London, Pan Macmillan.

BUELL Lawrence, 2005, The Future of Environmental Criticism: Environmental Crisis and Literary Imagination, Oxford, Blackwell Publishing.

BRAYTON Daniel, 2011, "Shakespeare and the Global Ocean", in L. D. Bruckner and D. Brayton (eds), Ecocritical Shakespeare, Farnham, Ashgate, pp. 173-90.

BRAYTON Daniel, 2012, Shakespeare's Ocean: An Ecocritical Exploration, Charlottesville, University of Virginia Press.

DAVIDSON Lynn, 2015, "Repetition, Return and the Negotiation of Place in The Tree House", in R. Falconer (ed.), Kathleen Jamie: Essays and Poems on Her Work, Edinburgh, Edinburgh University Press, pp. 93-100.

DeLoughrey Elizabeth, 2007, Roots and Routes: Navigating Caribbean and Pacific Island Literatures, Honolulu, University of Hawai'i Press.

FALCONER Rachel, 2015, “Midlife Music: The Overhaul and Frissure”, in R. Falconer (ed.), Kathleen Jamie: Essays and Poems on Her Work, Edinburgh, Edinburgh University Press, pp. 156-68.

FishER-WiRTH Ann \& STREET Laura-Gray, 2013, The Ecopoetry Anthology, San Antonio, Trinity University Press.

GARRARD Greg, 2012, Ecocriticism, New York, Routledge. 
HEIM Otto, 2010, "Breathing Space: Ecology and Sovreignty in Pacific Island Poetry", Dreadlocks: Oceans, Islands and Skies, vol. 6/7, pp. 141-73.

"Interview: Robin Robertson, Poet and Publisher", 2010, Scotsman. Available on $<$ www.scotsman.com/lifestyle/culture/books/interview-robin-robertson-poet-andpublisher-1-474043> (consulted 16 September 2016).

HEISE Ursula, 2006, “The Hitchhiker's Guide to Ecocriticism”, PMLA, vol. 121, no. 2, pp. 503-16. JAMIE Kathleen, (2004), The Tree House, London, Picador.

KERRIGAN John, 2008, Archipelagic English: Literature, History, And Politics 1603-1707, Oxford, Oxford University Press.

MACK John, 2011, The Sea: A Cultural History, London, Reaktion Books.

MACKAY Peter, 2015, “The Tilt from One Parish to Another: The Tree House and Findings", in R. Falconer (ed.), Kathleen Jamie: Essays and Poems on Her Work, Edinburgh, Edinburgh University Press, pp. 84-93.

MACKenZIE Garry, 2013, “Utopias, Miniature Worlds and Global Networks in Modern Scottish Island Poetry”, Green Letters, vol. 17, no. 3, pp. 200-21.

MENTz Steve, 2009a, “Toward a Blue Cultural Studies: The Sea, Maritime Culture, and Early Modern English Literature", Literature Compass, vol. 6, no. 5, pp. 997-1013.

MENTZ Steve, 2009b, At the Bottom of Shakespeare's Ocean, London, Bloomsbury Methuen Drama.

MENTZ Steve, 2015, Shipwreck Modernity: Ecologies of Globalization, 1550-1719, Minneapolis, University of Minnesota Press.

NAYLOR Paul, 1999, Poetic Investigations: Singing the Holes in History, Illinois, Northwestern University Press.

PETERS Kimberley \& ANDERSON Jon, 2014, “A Perfect and Absolute Blank”, in Water Worlds: Human Geographies of the Ocean, Oxon, Ashgate, pp. 3-23.

Peters Kimberley \& STEINBERg Peter, 2014, "Volume and Vision: Fluid Frames of Thinking Ocean Space”, Harvard Design Magazine, no. 35, pp. 124-29.

Peters Kimberley \& Steinberg Peter, 2015, “Wet Ontologies, Fluid Spaces: Giving Depth to Volume Through Oceanic Thinking", Environment and Planning D: Society and Space, vol. 33, pp. 247-64.

PUGH Jonathan, 2013, "Island Movements: Thinking with the Archipelago", Island Studies Journal, vol. 8, no. 1, pp. 9-24.

Pocock J. G. A., 2005, The Discovery of Islands: Essays in British History, Cambridge, Cambridge University Press.

ROBERTSON Robin, 2010, The Wrecking Light, Basingstoke, Picador.

SLOVIC Scott, 2010, "The Third Wave of Ecocriticism: North American Reflections on the Current Phase of the Discipline", Ecozono, vol. 1, no. 1, pp. 4-10.

STEINBERG Philip, 2014, “Foreword: On Thalassography", in P. Kimberley and J. Anderson, Water Worlds: Human Geographies of the Ocean, Oxon, Ashgate, pp. XIII-XVII.

"Suspension, n.", 2016, OED Online, Oxford University Press (consulted 6 September 2016).

“Terraqueous, adj.”, 2016, OED Online, Oxford University Press (consulted 6 September 2016). 


\section{NOTES}

1. Defined as "consisting of, or formed of, land and water" (OED, 2016, web) the term "terraqueous" importantly does not incur a rejection of "landed" or "grounded" constructions of place, but points us towards the equal significance of water in constructing relationships to place.

2. Despite his initial concept of ecocritical waves, Buell almost immediately suggests that the term "palimpsest" is more accurate: "No definitive map of environmental criticism in literary studies can [...] be drawn. Still, one can identify several trend-lines marking an evolution from a 'first wave' of ecocriticism to a 'second' or newer revisionist wave or waves increasingly evident today. This first-second wave distinction should not, however, be taken as implying a tidy, distinct succession. [...] In this sense, 'palimpsest' would be a better metaphor than 'wave'." (2005, p. 17)

3. Selkies, also known as "Roane" in Irish, are mythical creatures that appear as seals in the sea, shedding their skins to assume a human form once on land.

4. Notably her non-fiction collection Findings (2005) published shortly after The Tree House visits many of the same sites and creatures as the poems and similarly expresses an ecological ethics of listening to saltwater spaces.

\section{ABSTRACTS}

Analysing the poetic seascapes within Kathleen Jamie's The Tree House (2004) and Robin Robertson's The Wrecking Light (2010) this article examines the ecological and geopolitical parameters of the so-called "saltwater turn" in contemporary Scottish poetry. Invoking saltwater space as a means of uncovering new environmentally tuned poetic framings the article suggests that Jamie and Robertson's collections contribute to a growing field of archipelagic poetics which attends to the cultural, historical, and material interplay between the seas, oceans, and islands of the Atlantic archipelago. Exploring the dimensions of "blue ecology", their work encourages us to fathom new relationships with the nonhuman world whilst also critiquing cultural models which have long cast Scotland as a "marginal" or "fringe" literary space.

À travers l'analyse de la poétique des paysages marins de The Tree House de Kathleen Jamie (2004) and The Wrecking Light de Robin Robertson (2010), cet article examine les paramètres écologiques et géopolitiques d'un «tournant marin » [pour évoquer le «tournant linguistique » connu au milieu du $\mathrm{xx}^{\mathrm{e}}$ siècle par la philosophie et l'histoire notamment] dans la poésie écossaise contemporaine. Suggérant que l'espace marin est un moyen de révéler de nouveaux cadres poétiques modelés sur l'environnement, cet article entend démontrer que les recueils de Jamie and Robertson contribuent à un champ, en pleine expansion, d'une " poétique des archipels ", qui se préoccupe de l'effet culturel, historique et matériel du jeu conjugué entre mers, océans, et îles de l'archipel atlantique. À travers l'exploration des diverses dimensions d'une "écologie bleue ", ces travaux nous encouragent à sonder les relations nouvelles qui s'instaurent entre monde humain et non humain, tout en critiquant les modèles culturels qui ont depuis longtemps cantonné l'Écosse à la marge de l'espace littéraire. 


\section{INDEX}

Mots-clés: écopoétique, littérature écossaise contemporaine, poétique des archipels, « écologie bleue ", Robin Robertson, Kathleen Jamie

Keywords: ecopoetry, contemporary Scottish literature, archipelagic poetics, "blue ecology", Robin Robertson, Kathleen Jamie

\section{AUTHOR}

\section{ALEXANDRA CAMPBELL}

PhD candidate, English literature, School of Critical Studies, University of Glasgow. Alexandra Campbell is a current doctoral candidate in English literature at the University of Glasgow. Her thesis “Archipelagic Poetics: Ecology in Modern Scottish and Irish Poetry" presents a series of ecocritical readings of modern Scottish and Irish poets in line with geological, biological and oceanic coordinates. She teaches in both the Scottish literature and English literature departments at GU and is the current General Editor of EnviroHum, a new interdisciplinary and experimental zine and digital platform for artists and academics working in the Environmental Humanities. 